\title{
Thoughts of Fazlur Rahman Education and Its Contribution to The Development of Islamic Education Theory
}

\author{
Parisaktiana Fathonah \\ Faculty of Tarbiyah and Teacher Science \\ Universitas Islam Negeri Sunan Kalijaga, Yogyakarta \\ email: parisaktianafathonah@gmail.com
}

\begin{abstract}
This study aims to discuss the thoughts of education by Fazlur Rahman and its contribution to the development of Islamic education theory today. The data were collected through documentation method. The collected data were considered as documents, which were then read and understood to find necessary data based on the research problems in this study. After the necessary data were considered sufficient, they were systematized for further analysis. Fazlur Rahman as one of the reformers in Islamic education contributes by offering a more emphasis on development strategies in areas that are part of the education system itself, as well as integrating two types of sciences, in order to avoid disintegration in education and gap between them. Rahman's ideas in the renewal of Islamic education focus on the purpose of education, education system, learners, educators, educational facilities, and Islamic education curriculum.
\end{abstract}

Keywords :

Fazlur Rahman, Educational Thought, Islamic Education Theory

\section{Introduction}

Prolonged polemics in Islamic education continues to culminate in how to integrate religious science and general science towards the level of implementation. However, in its ideal concept, Islam has never known 
dichotomy on science. The Prophet said that whoever wants the world then, one can do it with science, and whoever wants the hereafter, it must be done with science; there is no priority or domination over both.

Non-dichotomy education is a type of Islamic education that does not connotes solely on the values of education associated with al ulum al dunyawiyah or also not merely connotes to al ulum al kauniyah. In reality, the integration process also covertly relates or encompasses to interests that have not given up the importance of building an integrated system of Islamic education. Islamic education that still distinguish ulumuddin and ulumuddunya does not deserve to be called as kaffah or comprehensive Islamic education. The separation between revelation and reason, religion and nature, the divorce between written revelation and unwritten revelation is the universe (Ikhtiono, 2014: vii).

Fazlur Rahman, a renowned reformer of the 20th century and who had great influence in Pakistan, Malaysia, Indonesia, and other countries (in the Islamic world) including Chicago, USA (in the Western world) had various thoughts related to this issue. He succeeded in being critical of both Islamic heritage and Western tradition, in which he developed a method that could provide alternative solutions to the problems of contemporary Muslims. Originally, he developed historical criticism method, in which he developed it further into a more systematic interpretation method, and finally refines into a double movement method (Sutrisno, 2006: 1).

If one follows Fazlur Rahman's way of thinking throughout his work, one will know that he was very concerned to awaken Muslims' consciousness of his historical responsibilities with a solid moral foundation. This foundation is only possible to be created when one uses Qur'an as the source of perfect moral teaching and fully and coherently understands the contents. This proper and complete understanding must be done through accountable methods both religiously and systematically. According to Fazlur Rahman, without a precise and comprehensive 
methodology, the understanding of Qur'an contents might be misleading, especially when it was approached partially and separately.

Based on the above description, this paper will discuss the concept of education based on Fazlur Rahman and how is Fazlur Rahman's contribution to the development of Islamic education theory. For theoretical framework, this study will be use the Islamic education theory. According to Zakiyah Daradjat, is synonymous with the word tarbiyah (in Arabic). Islamic education is the translation of tarbiyah Islamiyah, which is understood as a process to develop human nature according to his teachings (influence from outside) (Daradjat, 1992: 25). Naquib al-Attas emphasized Islamic education as a process for shaping Muslim (Islamic) personality (Al-Attas, 1979: ix). Omar Mohammad al-Toumy asy-Syaibany argued that education is a process of growth and acquiring experience in individuals and groups through interaction with nature and life environment (Al-Syaibany, 1979: 399). Yusuf al-Qardhawi mentioned that Islamic education is whole education process of human, their mind and heart, spiritual and physical, morals and skills. Islamic education prepares people to live in peace and at war, and prepare them to face the society with all its good and evil, whether it is a sweet or bitter life (Al-Qardhawi, 1980: 39). Hasan Langgulung formulated Islamic education as a process of preparing the young generation to fill the role and transferring knowledge and Islamic values that are harmonized with the human function to charity in the world and reap the rewards in the afterlife (Langgulung, 1995: 94).

From these insights, it can be seen that Islamic education has various factors, such as students, teachers, curriculum, facilities, and environment. The curriculum becomes one of the most important educational factors. Hilda Taba, when discussing the curriculum, started his argument from the analysis of education crisis (Taba, 1962: 1-3). It can be understood that if there is a crisis in the world of education, curriculum is one factor that need to be improved first. Then, educational experts make curriculum 
improvements as a general pattern for improving education.

Curriculum is originally used in the world of sports, especially athletic, with the understanding of running a course or race a course, especially during a chariot race. It is understood as a certain distance that must be taken within a certain time (from start to finish). Then the term is used in the world of education with the understanding as a number of subjects that must be taken within a certain time to achieve a certain (diploma) program (Sutrisno, 2006: 22-23).

Through the study of various books on the curriculum, it can be seen that the educational curriculum consists of four main components: objectives, materials, methods, and evaluation. The purpose of Islamic education is something that will be achieved by students through the process of education itself. The goals of Islamic education usually include aspects of knowledge, values, and skills. Islamic education materials, in the form of subjects, are used as contexts in the learning process to achieve its goals. The method of education is the learning process from preparation to evaluation. Educational evaluation is used to determine the learning outcomes that the students have achieved. These four elements of curriculum will be used to view the concept of education according to Fazlur Rahman.

\section{Literature Review}

In order to provide complete information regarding Islamic education through the existing studies, the researcher conducted research and obtained some works that can be used as a review in writing this paper. They are elaborated in the following sections:

Ahmad Syafi'i Ma'arif wrote under the title "Knowing Fazlur Rahman and His Thoughts on Islam." In his writings, Ma'arif categorized Fazlur Rahman as one of the most prominent figure in complete renewal of Islamic thought. Judging from his way of thinking, Rahman had an 
analytical, systematic, communicative, serious, clear, and courageous way of thinking in search for solutions to the problems of Islam and its people. Finally, Ma'arif came to a conclusion that Rahman is a scholar with orientation to Qur'an (Sutrisno, 2006: 3-4).

Nurcholis Madjid wrote under the title "Fazlur Rahman and Reconstruction of the Qur'anic Ethic". He considered that Rahman was very critical towards Islamic thoughts that are not rooted in history and are irrelevant to the development of society. A development of Islamic thought that is not rooted in the richness of classical Islamic thought or escapes the ability to trace the thread of its continuity with the past is considered as inauthentic. Madjid also considered that Rahman always adhered to the classic adage, "Every effort of Islamic reform should return to the Holy Book (Qur'an) and the Sunnah of the Prophet" (reference). He concluded that Rahman was a 'newspaperic' and was very competent in the perspective of historical criticism (Muhaimin, 1999: vii-xx).

Muhaimin's research entitled “Fazlur Rahman's Controversy Thought: The Critical Study of Renewal of Islamic Education" emphasized Rahman's thinking in the modernization of Islamic education. The core of that thought is the discussion on educational factors including educational goals, education systems, learners, educators, and educational facilities. Muhaimin found that the purpose of Islamic education, according to Rahman, should be oriented to the happiness of life in the world and in the afterlife, which comes from Qur'an. Rahman considered in order to eliminate the psychological burden of Muslims in facing the West is to conduct a thorough Islamic study, historically or systematically. In addition, the attitude of Muslims to science must be positive because there is nothing wrong about science. In case of error, it is the fault of the users.

One should immediately seek the solution to Islamic education system showing dichotomy or separation between the traditional (Islamic) and modern (secular) system. The problem-solving process of this 
problem can be done by integrating between sciences studied in traditional education system and those studied in modern educational system both organically and thoroughly. As a result, one day, the Islamic educational system can produce scientists like Ibn Sina, al-Kindi, al-Farabi, and Ibn Rushd. They were both theologians and prominent figures in general sciences because they did not discriminate the two. In principle, science is one, which is the one from the Almighty God. partly revealed through the verses of Quraniyah and others through the verses Kauniyah (Muhaimin, 1999:110).

\section{Research Methods}

In this study, the data sources used are self-written works by Fazlur Rahman, such as "Islam and Modernity: on Intellectual Transformation" and other works that elaborated his thoughts especially in the field of Islamic education. The data were collected through documentation method. The collected data were considered as documents, which were then read and understood to find necessary data based on the research problems in this study. After the necessary data were considered sufficient, they were systematized for further analysis. Further, the researcher conducted interpretation of what is implied behind the data. If necessary, comparison with the results of research or works of other thinkers was also carried out to provide more in-depth interpretation. This was done in order to understand and formulate the concept of education according to Fazlur Rahman through a more objective and critical lens.

\section{Biography of Fazlur Rahman}

Fazlur Rahman, a reformer who had a major influence in the twentieth century, had many thoughts related to education. He succeeded in being critical of both Islamic heritage and Western traditions. Fazlur Rahman developed a method that could provide alternative solutions to the problems of contemporary Muslims (Zuhri, 2016: 47-68).

DINIKA, Volume 3, Number 3, September - December 2018 
Fazlur Rahman was born on 21 September 1919, precisely in the present day Hazara (Indian-British Region) of Pakistan. His education began from a religious family environment. He grew up in a Hanafi family with a school of the most rational among the Sunnis (Zaprulkhan, 2014: 317-346). His father, Maulana Sahab al-Din was a well-known pious man of Douband graduates. His father noticed Rahman in terms of reciting and memorizing Qur'an, so at the age of 10 he was already able to memorize the whole Qur'an (Amiruddin, 2000: 50). Education in his family was extremely effective in shaping his character and personality to be able to face real life. According to Rahman, there were several factors affecting one's (particularly, his) character and religious depth. The most important factor was his father's persistence in teaching religion to him at home with high discipline. Therefore, he was able to cope with various civilizations and challenges in the modern world, in addition to the teachings of his mother, especially about his honesty, compassion and loving heart (Nata, 2013: 315-316). Another thing influencing Rahman's religious thought was the fact that Rahman was educated in a family with mazhab Hanafi tradition, a mazhab in Sunni that used more logical thought than the other maz̧ab (Sutrisno, 2006: 61). Although he was a Sunni follower, his thinking in recent times was very critical against Sunni and Shi'a. In other words, Rahman was a very critical figure in looking at his surrounding social phenomena (Bashori, 2016: 23-44). Abd. Rahman assegaf explained that Fazlur Rahman used a lot of logical thinking because India had developed somewhat liberal thinking, as developed by Muhammad Iqbal.

After graduating from high school in 1942, he successfully completed his studies at the University and earned Master's Degree in Arts. In 1946, Rahman continued his doctoral studies at Oxford University, preparing his dissertation on Psychology of Ibn Sina under the supervision of Professor Simon Van Den Bergh and succeeded in earning his doctorate of philosophy in 1951 (Iqbal, 2015: 591-592). When Fazlur Rahman studied 
at Oxford University, he studied a number of western languages, including Latin, French and German, as well as languages in the Islamic world such as Arabic, Persian and Turkish. Of course these Arabic languages are crucial in the development of Islamic knowledge area during his study and research life (Tarbiyah, 2010: 8). By the time he finished at Oxford University, Fazlur Rahman did not return to his country. For several years he taught in Europe, especially Persian and Islamic Philosophy at the University of Durham England. Subsequently, he moved from England to become an Associate Professor of Islamic Studies at McGill University's Institute of Islamic Studies in Montreal, Canada (Nata, 2013: 316).

After teaching for three years in Canada, Fazlur Rahman then embarked on a project dealing with efforts to contribute to the development of his country. Pakistan, under General Ayyub Khan, began renewing their efforts on the formation of political and State identity (Nata, 2013: 317). In 1960, Rahman returned to his country and two years later he was appointed as the Director of the Islamic Research Institute (Tarbiyah, 2010: 9). In addition, in 1964, Rahman was appointed as a member of the Pakistani Islamic Ideology Advisory Council (Nata, 2013: 317). The institute aimed to interpret Islam and rational and scientific terms in order to respond to the challenges of modern progressive society (Alyafie, 2009: 29-52). Meanwhile, the Islamic Ideology Advisory Board was in charge of reviewing all laws, both those already and those not yet established, with the aim of aligning them with Qur'an and Sunnah. Both institutions had close cooperative relationships, as the Advisory Board may request research institutions to collect materials and propose advice in drafting laws (Adnan, 1993: 13-14). However, in 1969, he left his position as a member of the Pakistani Islamic Ideology Advisory Board after a few moments before he resigned from his position as the Director of the Islamic Research Institute. After releasing his two positions in Pakistan, Rahman moved to the West. At that time, he was accepted as a lecturer at

DINIKA, Volume 3, Number 3, September - December 2018 
the University of California, Los Angeles, USA. In 1969, he began serving as a Professor of Islamic Studies in various aspects at the Department of Near Eastern Languages and Civilization, University of Chicago. He settled in Chicago for 18 years, until he died on July 26, 1988 (Nata, 2013: 317-318).

\section{The Concept of Education by Fazlur Rahman}

According Rahman, Islamic education is not just equipment and physical equipment or quasi physical teaching such as books or external structure of education. It also serves as Islamic intellectualism because this is the essence of Islamic higher education. This represents the growth of genuine and adequate Islamic thought, and should provide the criteria for assessing the success or failure of an Islamic education system.

According to the observers of Islamic thought, Fazlur Rahman was a figure whose thoughts were categorized as neo-modernist, a pattern of thought that combines modern and traditional thinking. Modernism according to this pattern is not something to be rejected, and modernism does not mean setting aside the nature of traditionalism. This is certainly in line with Islamic thought and Fazlur Rahman who always developed his thoughts to see the development of historical thinking (Ajahari, 2016: 232-262). Abd. Rahman Assegaf explained that Fazlur Rahman used logical thinking because liberal thinking is more developed in India, as developed by Muhammad Iqbal (Assegaf, 2010: 120).

The appearance of Fazlur Rahman gave hope for the future of Islam, because in addition to offering what he called Islamic neo-modernism, he also provided a new interpretation of the slogan 'back to the Qur'an and Sunnah.' Although it is realized as a long term objective because the spread and its application must be done by educated people, and it can only be realized through education (Hidayah, 1988). Based on Qur'an, Rahman's educational purpose is to develop human beings, so that all the 
knowledge he gained will be the organ of a creative person, enable man to harness the resources of nature for the good of mankind and to create justice, progress, and orderliness of the world (Sutrisno, 2006: 170-171).

Rahman, with his critical attitude to historical data, had been able to precisely judge the valuable assessments of Islamic education development, from classical times to modern times, in terms of both advantages and disadvantages. By recalling the history of Islamic education, he emphasized the importance of giving new ideas, so that Islamic education could achieve its objectives. However, there are some weaknesses in Islamic education. First, education in the Muslim world is basically the continuation of colonial age education. Second, if not appropriately adjusted, education in traditional religious institutions will decline. Third, modern education, in the sense of its association with technology, has taken the prestige position formerly possessed by traditional education. The visible impact of such conditions is the occurrence of disintegration, which in later stages implies the inability of Islamic education to improve the intellectual standard of its people (Iqbal, 2015: 606-607).

According to Rahman, although there had been many efforts in formulating Islamic education, none of them was able to solve the problems because the root of the problem has not been discussed. Rahman saw that all forms of problems that exist lead to the ability to expand Muslims' intellectual insight by improving their scientific standards, and at the same time still have a high commitment to Islam. Rahman explicitly said that they must distinguish between historical and normative Islam, so that the real concept of science in Qur'an can be clearly illustrated. This is an alternative to solve the infinite circle of problem. Based on this distinction, the existence of a systematic reconstruction of Islamic sciences will be capable of capturing the basic message of the Qur'anic teachings.

DINIKA, Volume 3, Number 3, September - December 2018 


\section{Basic of Education}

Fazlur Rahman's thoughts in education and others were built on the basis of his deep understanding of Islamic intellectual treasures in classical times to find his spirit to solve the problems of modern life. This can be seen from the analysis given to the growth and development of Islamic education which began from the time of Abbasid. He said that the Islamic education implemented during the classical era applied the method of reading and writing, but the most common implementation is to memorize Qur'an and Sunnah. However, there were also small groups sought to develop intellectual abilities. Then, at the time of the Abbasids, certain caliphs such as Harun al-Rashid and al-Ma'mun emphasized the arguments among students in the palace on the matter of logic, law, grammar and so on.

Through his study of the classical literatures, Fazlur Rahman introduced his ideas and thoughts on educational reform. He said that the renewal of Islamic education can be done by receiving modern secular education, then attempting to integrate it with Islamic concepts. The efforts to reform this Islamic education can be pursued by: first, evoking Muslims' ideology about the importance of learning and developing science. Second, trying to erode the dualism of Islamic education system. On the one hand, there is traditional education (religion), and on the other hand, there is a modern (secular) education. Therefore, there should be an effort to integrate between the two. Third, realizing the importance of language in education and as a tool for issuing original opinions. In fact, he said that Muslims are a society without language. Fourth, the renewal in the field of Islamic educational methods, namely shifting from the method of repeating and memorizing lessons to methods of understanding and analyzing (Nata, 2013: 319-320). 


\section{Definition of Education}

Education can include two major insights. First, Islamic education in a practical sense, that is education carried out in Islamic world such as those held in Pakistan, Egypt, Sudan, Arabia, Iran, Turkey, Morocco and so on, from basic education to college. For the context of Indonesia, including education in pesantren (Islamic boarding school), in madrasah (from Ibtidaiyah to Aliyah), and in Islamic University, and even Islamic education in schools (from basic to advanced) and Islamic education in public universities. Secondly, Islamic higher education is called Islamic Intellectualism. Furthermore, Rahman's Islamic education can also be understood as a process for the process of producing integrative human beings (scientists), on which collected qualities such as critical, creative, dynamic, innovative, progressive, fair, honest, and so on. Such scientists are expected to provide an alternative solution to the problems faced by mankind on earth (Nata, 2013: 320).

\section{Educational Purposes}

Purpose is an ideal atmosphere to be realized. In the educational goal, the ideal atmosphere appears to the ultimate goal. The ultimate goal is usually formulated in solid and concise terms, such as the formation of Muslim personality (Marimba, 1989: 49), personal maturity and integrity (Djamal, 1983: 157).

According to Fazlur Rahman, the purpose of education is to develop human beings in such a way that all the knowledge they gain will be the organ to create a creative person, enable people to utilize the natural resources for the good of mankind and to create justice, will, and order of the world. In addition, the purpose of education, according to Fazlur Rahman, also emphasized the moral aspect. He mentioned that the first educational responsibility is to instill in moral values in the students' minds. Islamic education is based on Islamic ideology. Therefore, in 
essence, Islamic education cannot abandon its involvement in right and wrong perceptions. Therefore, the main goal of education is to save people from their ego. In addition, education should not only emphasize the cognitive aspects, but also the affective and psychomotor aspects (Djamal, 1983: 320-321).

\section{Curriculum}

Curriculum is a design of learning, and without the curriculum, learning process cannot run maximally. Fazlur Rahman's view of curriculum departs from the narrowing of general science field due to the absence of general thinking and deep-scaled science, thus causing curriculum to be confined to pure religious sciences. In order to gain broader knowledge, a student should not only study one particular field of study, but also master other fields. Therefore, Rahman advocated renewal in a religious-based curriculum by adding general science-based curriculum or otherwise incorporating religious values in modern curriculum (Ikhtiono, 2014: 32).

\section{Education System}

In the development of Islamic education, Rahman noted that there are two basic approaches to modern knowledge. First, the acquisition of modern knowledge is limited only in the fields of practical technology due to the belief that Muslims do not require western intellectual products and such products need to be avoided since it will cause doubt and confusion in Muslim minds. It is also believed that traditional Islamic belief systems have provided satisfactory answers to the world's top questions of worldview. Secondly, Muslims can and must acquire courageously not only western technology but also their intellectualism because it can be harmful knowledge, and after all, science and knowledge were actively cultivated by Muslims during the early centuries, which was later taken over by the Europeans (Iqbal, 2015: 618). 


\section{Educators and Learners}

Educators in Islamic education are interpreted as people who are responsible for the development of students' intelligence by seeking the development of all potential students, whether it is affective, cognitive, or psychomotor potentials (Iqbal, 2015: 622).

Fazlur Rahman's perspectives about students include the fact that students should be given Qur'an lessons through methods that enable the holy book to be not only the source of moral inspiration but also the highest reference to solve complex problems in everyday life. Second, teachers should provide materials on the discipline of Islamic sciences historically, critically, and holistically. The disciplines of Islamic sciences include theology, law, ethics, the social sciences and philosophy (Muhaimin, 1999: 111-112).

\section{Methods of Education}

In this case, Fazlur Rahman did not directly mention the methods of education he suggested, but there are several methods he revealed that can be closely associated with education. Among these methods, the method of historical criticism, the method of systematic interpretation, and the method of a double movement are the most suitable ones to be included (Sutrisno, 2006: 121-134).

\section{The Critical History Method}

The Critical History Method which has been applied in writing his sharp and critical thoughts is then developed into a systematic methodical method, which is called the systematic interpretation method (Bashori, 2016: 23-44).

The method of historical criticism is the disclosure of values contained in some historical data, not the historical event itself. If historical data are chronological, it will be called historical approach. In practice, 
rather than focusing on the chronology of education in the Islamic world, this approach emphasizes the values contained in the historical data of Islamic education in the world. Specifically, this method is applied by describing the historical values of Muslim education, especially in Turkey, Egypt, Iran, Pakistan and Indonesia, and occasionally Rahman makes comparisons between the education systems in those countries. Therefore, by implementing historical criticism method, Fazlur Rahman emphasizes on the values contained in the history of Islamic education.

\section{The Systematic Interpretation Method}

Fazlur Rahman puts forward systematic interpretation method, consisting of three main steps. First, the historical approach to discover the meaning of the Qur'anic text in the expanse of the Prophet's career and struggle. Second, distinguishing between legal accuracy and its objectives and the objectives of Qur'an. Third, understanding and establishing Qur'an by fully exposing its sociological background. It is these characteristics that interpret the content of the Qur'an. This method inclines more on Fazlur Rahman's interpretation of Qur'an.

\section{A Double Movement Method}

Fazlur Rahman was very critical towards Islamic thoughts that are not rooted in history and are irrelevant to the development of society. This attitude may also be due to his own intellectual interests and tendencies, as he believed that a development of Islamic thought that is not rooted in the glory of classical Islamic thought or escapes the ability to trace the thread of continuity with the past is considered as inauthentic (Saefuddin, 2003: 146-149).

In addition, Fazlur Rahman also suggested that the movement of handling concrete cases in Qur'an is done by taking into account the relevant social conditions at that time to the general principles where the 
religious teachings are centered in. Secondly, from the general rankings, the movements should be made back to its specific legislation by taking into account the present social conditions (Rahman, 2005: 9). For that reason, the combination of contemporary contexts cannot be separated from the historical context that became the basic understanding of what is relevant for all.

The double movement method, in which the movement from the present situation influences the historical period during Qur'an revelation, and then it also influences the present. This method can be done with Qur'an or interprets Qur'an in its context and envisages it to the present situation.

\section{Fazlur Rahman's Thoughts and its Contribution to the Development of Islamic Education Theory}

For Rahman, education is the starting point for renewal. Any renewal model in Islam will never happen without the involvement of education in it. Rahman mentions that educational reform is the only approach to a long-term solution to the problems faced by Islamic societies today (Muhaimin \& Mujib, 1993: 608).

Rahman believed that the congestion of intellectualism is the main cause of the emergence of secularism in the Islamic world during the premodernist times. This affects the course of modern Islam, particularly in the field of education, although there are substantial differences in the nature of modern developments in different Muslim regions (Zuraya, 2013: 185-200). Whether it is truly realized or not, in Islamic education in Indonesia there has been a scientific dichotomy which has resulted in the dullness of religious values in humans and the spirit to develop scholarship, which should have been the humans' main task as the Caliph of the world. Invisibly, the impact of scientific dictatorship gradually destroys the essence of Islamic education as a framework of beauty in scholarship.

DINIKA, Volume 3, Number 3, September - December 2018 
This situation prompted Fazlur Rahman to found ideas for a change in Islamic education. Rahman, with his critical attitude to historical data, had been able to provide a valuable assessment of the development of Islamic education, from classical times to modern times, and examines both its advantages and disadvantages. By recalling the history of Islamic education, he emphasized the importance of giving new ideas, so that Islamic education could achieve its objectives (Iqbal, 2015: 606-607).

Although much effort has been made in formulating Islamic education, it has not been able to solve the problems they faced, because the root of the problem has not been touched. Rahman saw that all forms of problems that exist lead to the ability to expand Muslims' intellectual insight by improving their scientific standards, and at the same time still have a high commitment to Islam.

As for addressing the issues of Islamic education, he offered a development strategy that was more emphasized in the areas that are part of the education system itself (Al-Khudari, 2017).

\section{Educational Purposes}

According to Rahman, the current strategy of Islamic education is not directed to a single positive goal, but a very defensive one, that is to save human mind from Western ideas that come through various disciplines, especially ideas that threaten traditional Islamic morality (Rahman, 2005: 102). Thus, the problem shows that the goal of Islamic education tend to be oriented in the hereafter.

Considering the issues that are not aligned, they are deemed as less precise with Fazlur Rahman's thinking. According to him, the goal of Islamic education that focused only for the afterlife and to defend against Western ideas must be changed immediately. Instead, it must be oriented to the life and the hereafter, which is derived from Qur'an (Muhaimin, 1999: 105). Thus, the unity of science that does not separate each other will complement both religious science and general science. 
In addition to the Islamic educational objectives taken from the Qur'an, Rahman's goal of education is to save man and to give birth to scientists who are able to integrate religious science and modern general sciences, which is characterized by the existence of critical and creative nature that can produce findings useful to mankind (Sutrisno, 2006: 5). In other words, it is important for Muslims to understand the need for integration of science so that they will obtain an understanding that is able to break the period and not lost to the future. In addition, Rahman's educational goals also emphasized the moral aspect. He said that the first educational responsibility is to instill students' minds with moral values. Islamic education is based on Islamic ideology (Nata, 2013: 321). In the end, whatever color of science mastered by the learner will bring the values of Islamic ideology in real life.

\section{Education system}

The classical discourse that is still frequently questioned is the dichotomy in the Islamic education system. Actually it should not happen, because the dichotomy is a Westernized educational system that is nationalized by adding some subjects of religion and Islamic education system that comes from the (not traditional) classical period that is not fundamentally updated, has different directions, or it becomes the contrary in some important aspects (Usa, 1991: 3). The problem of the dichotomy of the educational system - the separation of both sciences-and the question of dualism of the separated education system has plagued the existing education today. Indirectly, the separation will affect the partial way of looking at real life problems and the emergence of assumption that the afterlife is more important than science to stagnate the development of science among Muslims, especially in the field of general science. If so, humans will misunderstand Islamic teachings. Islam, which should have a universal doctrine, only has narrow space of life. Therefore, the division

DINIKA, Volume 3, Number 3, September - December 2018 
of knowledge dichotomy is not accepted by Islam because it contradicts Islamic teachings itself.

To solve the problem, Fazlur Rahman offered a solution, namely by removing the dichotomy by integrating religious science and general science in organic and comprehensive within the field of education. Basically, science is integrated and cannot be separated. Science is neutral and accessible for anyone. This method has been applied during the golden age of Islam. Besides studying religious science as a foundation, they also learned general science as a way to develop their mind. Therefore, the educational system built must place science as something neutral, something free of prejudice, as well as from the hegemony of certain groups. Science belongs to God, and anyone is entitled to acquire it. Therefore, Islamic education system should be open to anyone (Ikhtiono, 2014: 123-124).

\section{Learners}

For Rahman, science in principle is one, that is from the Almighty God (Iqbal, 2015: 620). However, the dichotomy of science in Islamic education system often arises as a problem. Although children get the science of education, they only receive religious sciences or general sciences. By receiving only one form of science, it will be very difficult for him/her to become a complete human being. The unsuccessful abolition of this dichotomy system results in low intelligence among students and the emergence of split personalities. This condition ultimately leads to double morality (Muhaimin \& Mujib, 1993: 234).

As the efforts to overcome this problem, Rahman did it with several methods. First, learners should be given Qur'an lessons through methods that allow the holy book to not only serve as a source of moral inspiration but also used as the highest reference to solve everyday life problems. Second, they should provide material discipline of Islamic 
sciences historically, critically, and holistically. The disciplines of Islamic sciences include theology, law, ethics, social sciences, and philosophy. Thus, the reconstruction of Islamic education actually only incorporates these sciences into subject units, instead of making Islam every subject (Ikhtiono, 2014: 126-127).

Fazlur Rahman's view of the students is an ideal view for the formation of superior Muslim personality, as in one person, the soul of Qur'an is formed and s/he has a very comprehensive range of disciplines. However, it is not something easy to achieve since the system and management of the existing education must be well integrated and ideal for now, so that it will be able to achieve the understanding of the whole knowledge in seeing the surrounding social phenomena.

\section{Education Facility}

Based on Fazlur Rahman's observations in several Islamic countries he visited, the education facilities show that the state of libraries in Islamic educational institutions is still not adequate to fulfill the need for knowledge, especially the number of books. The books available in the library of Islamic educational institutions are still very minimal, especially Arabic-language books and English-language books. To overcome these problems, Fazlur Rahman proposed that library facilities should be equipped with more Arabic and English-speaking books (Iqbal, 2015: 624-625).

With regard to education facilities, Fazlur Rahman prioritized the development of libraries. This is considered as important because scientific references are needed for the development of science, especially books in Arabic and English containing theories and the development of science from various countries. By implementing this method-complementing references in libraries, Islamic studies of various disciplines will be able to create new intellectual treasures.

DINIKA, Volume 3, Number 3, September - December 2018 


\section{Curriculum}

According to Rahman, by narrowing the field of general science through the absence of general thinking and natural science, the curriculum itself becomes limited to pure religious sciences with grammar and literature as a necessary tool. Whereas, the pure subjects have four pieces, namely Hadith (Tradition), Fiqh (Law) referred to Ushul Fiqh, Kalam (Theology), and Tafsir (Exegesis of Qur'an) (Rahman, 1984: 275).

Thus, to be a knowledgeable Muslim, a student should not only study a particular field of study, but also master other fields. Therefore, Rahman advocated renewal in a religious-based curriculum by adding a general science-based curriculum, as well as incorporating religious values in the modern curriculum (Ikhtiono, 2014: 131-132).

Based on the description, it can be understood that Fazlur Rahman's idea of renewal is very important for the development of Islamic science in the fore to be able to compete in modern world. Fazlur Rahman's ideas on the concept of science and other integrations are the doors that can encourage Muslims to gain their former glory after being captured by the Western world for so long.

\section{Conclusion}

Based on the results and discussion of this research, it can be concluded that the prolonged polemic in Islamic education continues to culminate in how to integrate religious science and general science towards the level of implementation. However, in its ideal concept, Islam has never known dichotomy on science. The Prophet said that whoever wants the world then, one can do it with science, and whoever wants the hereafter, it must be done with science; there is no priority or domination over both.

Scientific dichotomy is a problem that often appears within the realm of education, with the distinction made by both the organizers and the applied curriculum, in which the distinction often creates sad 
impression on the output of education itself. Clearly, there is a dichotomy or distinction between the religious sciences and the general sciences in the implementation of Islamic education in Indonesia. In essence, there is no difference of knowledge on the two types of science, because religious science can be perfectly incorporated within common science, and likewise, general science can be incorporated in religious science.

Fazlur Rahman as one of the reformers in Islamic education contributed in the field by offering a more emphasis on development strategies in areas that are part of the education system itself, as well as integrating the two sciences in order to avoid disintegration in education and eliminate the gap between them. Rahman's ideas on the renewal of Islamic education focused on the purpose of education, education system, learners, educators, educational facilities, as well as Islamic education curriculum.

From the results of this study, the researcher can suggest several points; first, In order to avoid dichotomy in education, it is important to integrate general sciences and religious sciences. Thus, it can create a wide and unlimited science, which will be able to solve problems that exist today. Second, It is expected that educators are able to develop the potentials found in learners.

\section{References}

Adnan, A. T. (1993). Fazlur Rabman dan Usaba-usaba Neo-Modernisme Islam Dewasa Ini. Bandung: Mizan.

Ajahari. (2016). Pemikiran Fazlur Rahman dan Muhammad Arkoun. Jurnal Studi Agama Dan Masyarakat, Vol. 12, No. 2, pp. 232-262.

Al-Attas, S. M. al-N. (1979). Aims and Objectives of Islamic Education. Jeddah: King Abdul Aziz University.

DINIKA, Volume 3, Number 3, September - December 2018 
Al-Khudari, A. F. (2017). Pengembangan Teori Pendidikan Fazlur Rahman. Paper, PPs UIN Sunan Kalijaga Yogyakarta.

Al-Qardhawi, Y. (1980). Pendidikan Islam dan Madrasah Hasan al-Banna. (B. A. Gani \& Z. A. Ahmad, Eds.). Jakarta: Bulan Bintang.

Al-Syaibany, O. M. al-T. (1979). Falsafah Pendidikan Islam. (H. Langgulung, Ed.). Jakarta: Bulan Bintang.

Alyafie, H. (2009). Fazlur Rahman dan Metode Ijtihadnya: Telaah Sekitar Pembaruan Hukum Islam. Hunafa, Vol. 6, No. 1, pp. 29-52.

Amiruddin, M. H. (2000). Konsep Negara Islam Menurut Fazlur Rabman. Yogyakarta: UII Press.

Assegaf, A. R. (2010). Pendidikan Islam Kontekstual. Yogyakarta: Pustaka Pelajar.

Bashori. (2016). Fazlur Rahman; Pendidikan Islam dan Relevansinya dengan Dunia Modern. Hikmah, Vol. 5, No. 1, pp. 23-44.

Daradjat, Z. (1992). Ilmu Pendidikan Islam. Jakarta: Bumi Aksara.

Djamal, M. (1983). Filsafat Pendidikan Islam. Jakarta: Proyek Pembinaan Prasarana dan Sarana PTA/IAIN.

Hidayah, Y. (1988). Fazlur Rahman: Kiai dari Chicago. Amanah, No. 60.

Ikhtiono, G. (2014). Konsep Pendidikan Nondikotomik dalam Perspektif Fąlur Rahman. Yogyakarta: Kaukaba Dipantara.

Iqbal, A. M. (2015). Pemikiran Pendidikan Islam Gagasan-gagasan Besar Para Ilmuwan Muslim. Yogyakarta: Pustaka Pelajar.

Langgulung, H. (1995). Beberapa Pemikiran tentang Pendidikan Islam. Bandung: al-Ma'arif.

Marimba, A. D. (1989). Pengantar Filsafat Pendidikan Islam. Bandung: alMa'arif.

Muhaimin. (1999). Kontroversi Pemikiran Fąlur Rabman: Studi Kritis Pembaharuan Pendidikan Islam. Cirebon: Pustaka Dinamika.

Muhaimin, \& Mujib, A. (1993). Pemikiran Pendidikan Islam Kajian Filosofis dan Kerangka Dasar Operasionalnya. Bandung: Trigenda Karya. 
Nata, A. (2013). Pemikiran Pendidikan Islam dan Barat. Jakarta: Rajawali Press.

Rahman, F. (1984). Islam. Bandung: Pustaka. . (2005). Islam dan Modernitas: tentang Transformasi Intelektual. (A. Mohammad, Ed.). Bandung: Pustaka.

Saefuddin, D. (2003). Pemikiran Modern dan Postmodern Islam: Biografi Intelektual 17 Tokoh. Jakarta: Gramedia Widiasarana Indonesia.

Sutrisno. (2006). Fazlur Rahman: Kajian terhadap Metode, Epistemologi, dan Sistem Pendidikan. Yogyakarta: Pustaka Pelajar. . (2006). Pendidikan yang Menghidupkan. Yogyakarta: Kota Kenang.

Taba, H. (1962). Curriculum Development Theory and Practice. New York: Harcount, Brace \& world, Inc.

Tarbiyah, T. P. F. (2010). Pendidikan Islam: Konsep, Aksi, dan Evaluasi. Yogyakarta: UIN Sunan Kalijaga.

Usa, M. (1991). Pendidikan Islam di Indonesia. Yogyakarta: Tiara Wacana.

Zaprulkhan. (2014). Filsafat Pendidikan Islam Studi Pemikiran Pendidikan Islam Fazlur Rahman. Episteme, Vol. 9, No. 2, pp. 317-346.

Zuhri, S. (2016). Relevansi Konsep Pendidikan Fazlur Rahman Dengan Kurikulum 2013. Genealogi Pendidikan Agama Islam, Vol. 3, No. 2, pp. 47-68.

Zuraya, H. (2013). Konsep Pendidikan Fazlur Rahman. Khatulistiwa, Vol. 3, No. 2, pp. 185-200.

DINIKA, Volume 3, Number 3, September - December 2018 